\title{
A PALAEONTOLOGICAL HOLIDAY $A$ visit to the Hunter Quarry near Eastend
}

\author{
by Mrs. Hope Johnson, Ralston, Alberta
}

Late last May I decided to take advantage of an invitation from Dr. A. G. Edmund of the Royal Ontario Museum to join their party which had begun its 1968 operations at Calf Creek some three weeks earlier. I live some 25 miles northwest of Medicine Hat, and decided to go to the Hanson Ranch via Piapot and southeast. I discovered that while this route is shorter, it is by no means the simplest way to go. Anyone familiar with back roads in this part of the country will know what I mean. It had rained recently, and the narrow roads were rough and rutted. A couple of farmers looked at me doubtfully and said they had never heard of Clintonel. However, I had a detailed map, and kept on until a cheery lady at a tiny cottage near Skull Lake assured me it was close by. Within short order I found myself on a newly graded road running down toward Eastend. (Clintonel was there too, tucked away in a wooded hollow.) Dr. Edmund had provided me with detailed directions to the quarry, and after calling at the ranch, and wrestling with a particularly decayed wire gate, I climbed the steep ridge behind the farm yard, and then descended quite suddenly (in fact, the trail appeared to vanish over a minor precipice at one point!) into the coulee where Calf Creek rises out of the ground amid large quartzite pebbles, and about a mile on, disappears mysteriously underground among the mossy roots of a tangle of shady trees.

I arrived in the early afternoon of a fairly hot day, and the first thing that I noticed about the coulee was the strong and agreeable scent of Silverberry (or "Wolf Willow"-Eleagnus commutata). There were two large stands of this shrub in the coulee, and they were in full bloom. Surely this powerfully scented flower has some commercial possibilities. How about a new Saskatchewan soap?

The main part of the R.O.M. party was up on a hillside on the east side of the valley, where, under a 30-foot cliff of cross-bedded sand, students and two technicians were working under Dr. Edmund's direction. At this point in the Cypress Hills, the upper levels are in the Cypress Hills formation, composed here of alternating sands, silts and lenses of hard conglomerate. The conglomerate has a very hard limy matrix in which are embedded hard quartzite pebbles and clayey concretions. Small fossils are found in the sands and silts, while the large items are mainly found in the hard conglomerate rock. It is believed that there was a lake in this area in early Oligocene time, some 45 million years ago. The animals of this period were mainly rather primitive forms of mammals known to us today - very early horses, large and small relatives of the rhinoceros-kin to the horses - called Brontotheres (Titanotheres); huge primitive "pigs" called Entelodonts with skulls up to 18 inches long; Oreodonts, grazers of sheep size long since extinct without leaving descendants; small carnivores rather like a raccoon; tiny primitive deer similar to the Chinese Water Deer and Dikdik of Southeast Asia today; crocodiles, turtles and fish, especially large catfish. The remains of the large animals seem to be found mainly on the upper surface of the conglomerate lenses, from which they have to be removed with gasolinepowered jackhammers and rock saws. The pit was a rather nasty place on windy days, since the cross-bedded sands above it were not consolidated, and constantly sifted down upon the operators of the power tools, and the searchers for new specimens. In fact, a few days after I left the area, 


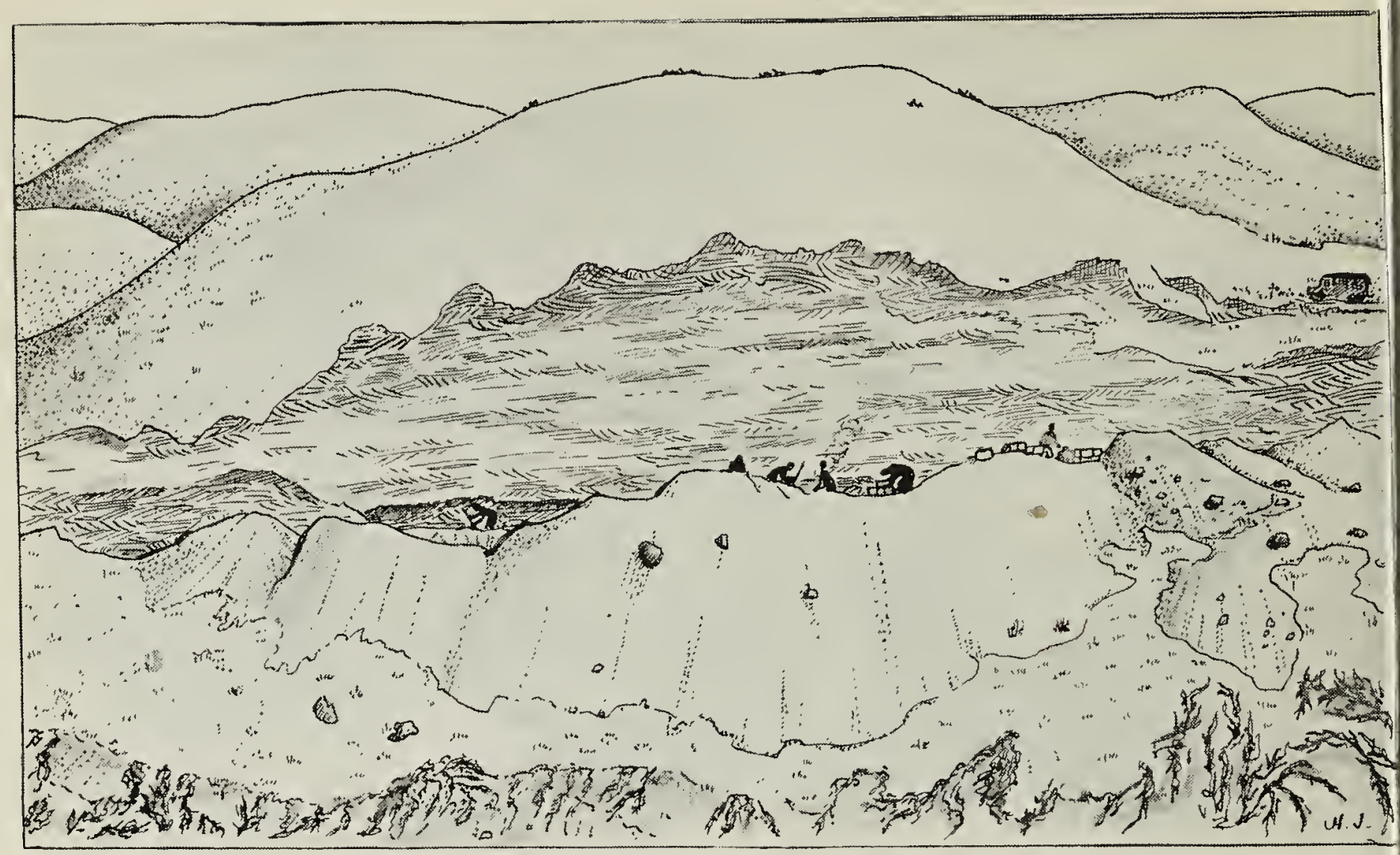

Hunter Quarry from west side of Calf Creek

heavy equipment was brought in, hired from the road contractors, to cut further back into the hillside. Evidently the sand was even looser in the new cut, because it soon collapsed into the pit, completely frustrating the "dig".

While hunting and digging and rock-cutting went on in the main quarry, two or three of the students (in all there were ten boys and two girls, all seniors at Toronto High Schools) would go off and prospect on the adjoining hillsides for small fossils, or any likely-looking outcrops with larger material. Some mechanical screening of sandy deposits had been done across the valley, but this particular deposit had pretty well been worked out.

Since looking for small fossils is more in my line, I went off with a couple of boys over the hill to the southwest. The conglomerate of these hillsides was much weathered, and often overgrown with Bearberry and various tufted grasses. The hills in this area are very arid, but there seems to be a spring-fed creek in every coulee, rising just above the Ravenscrag formation which is of
Paleocene age (maybe 60-55 million years old). Sandy spots abounded in tufts of Bladder-pod (Lesquerella alpina), while there were small stands of Low Larkspur in moister places. The best hunting spots were the most denuded hillsides, and there one could find, by getting one's nose quite close to the ground, the teeth and tiny bones of the small deer previously referred to. The teeth are like those of today's deer, but very small, from one-quarter to three-eighths of an inch across. The little bones of the fore and hind feet, with the tiny hoof bones (the horny hoof itself is not preserved as a fossil) are comparable in size to the foot bones of an average-sized rabbit, though unmistakably deer, not anything else. I was especially pleased to find a threequarter-inch long astragalus (an ankle element) of such an animal, which is identical in shape to that of a modern bison, or cow or deer. Most of these fossils are a light rusty tan colour, and well mineralized. I also found a cheek tooth (molar or premolar) of a small carnivore, rejoicing in the name of Pseudochynodictis, which was apparently an 
incestor of our dogs and wolves. There were lizard vertebrae, fragments of crocodile skull, turtle bones ind plates, a gar pike scale like those found in the dinosaur beds nearer lome, and vertebrae and spines from arge catfish. Judging from the size of these, and the very formidable ooking saws on the edges of the lorsal spines, these catfish must have been able to give an adversary plenty ff trouble. We found many fragments if very large Brontothere teeth, but cood intact specimens were another natter. Unlike their relatives, the rorses of today, these animals were rowsers with low-crowned molars, ind curious peg-like incisors. One tudent found a beautiful specimen of ne of these, exactly like a wooden ribbage peg, about one and a quarter nches long, with a knob-like enameled crown. These were used, Dr. Edmund said, to rip the leaves off ranches. There is a good deal of ossil wood in the Cypress Hills formation here, and so far as has been letermined to date, much of it is of road-leaved trees such as oak and lm. The theory is that the gradual hange from such woodlands to the ater grasslands spelled the end of the prowsing Brontotheres, whose not very lurable dentition could not make the ransition to a grass diet. It fact, we luite often found teeth in which lmost the entire enamel crown was worn away. This must have left the nimal in an awkward condition. Early horses had low crowned teeth, out strains which developed high rowned teeth were able to survive, o the horse is with us still. I found ome ankle elements of Brontothere, the astragalus recognizable by its esemblance to that of a modern horse, rather than the type seen in he cattle, sheep, deer group (Artioloctyla.)

While we were collecting on one hillside, we could see, on an adjoining hill, a little cave, to which an owl was making flights. With binoculars, we could see an owl, presumably a young one, sitting within the cave.

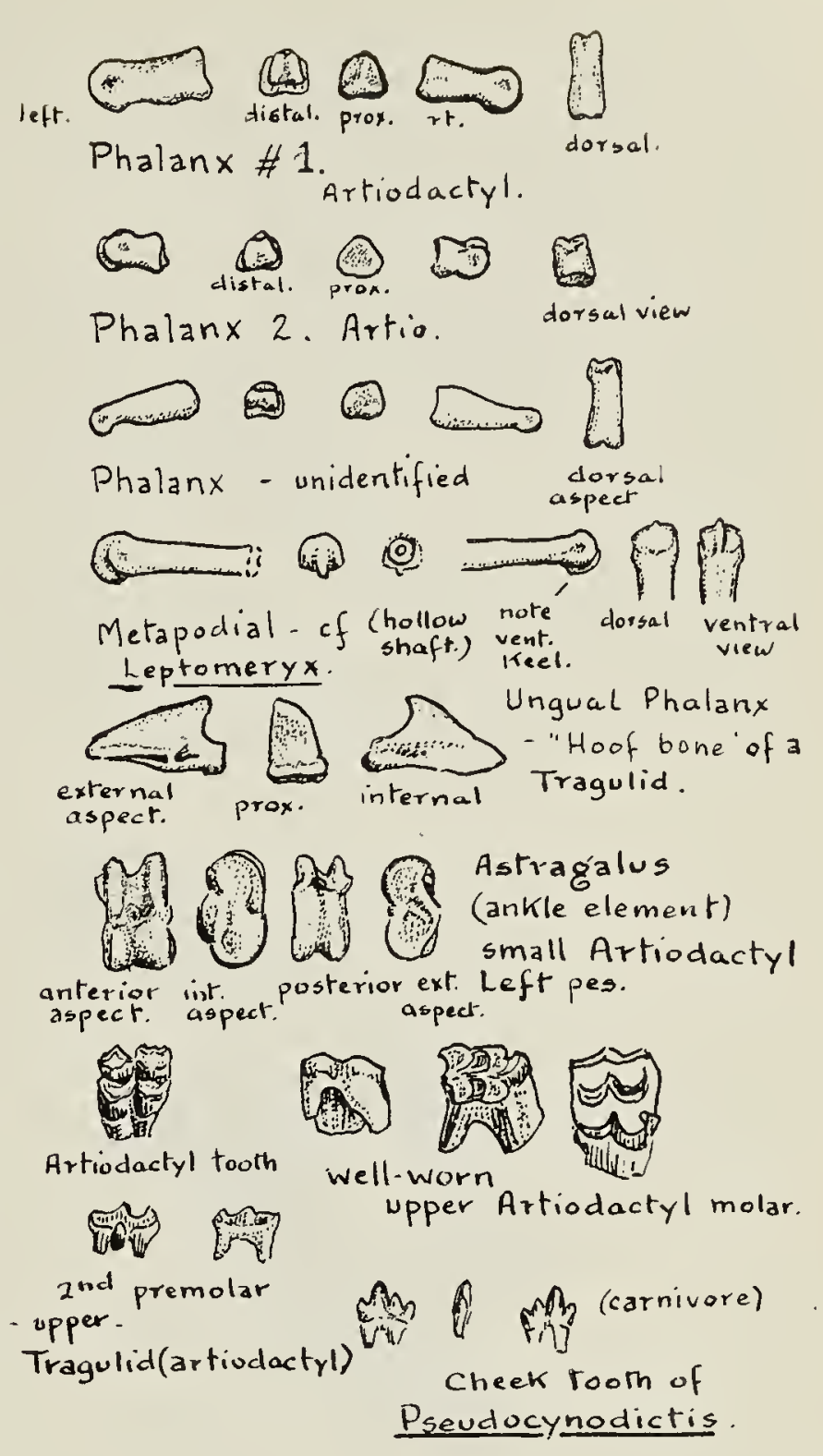

Fossils from Cypress Hills Oligocene, about $2 / 3$ natural size.

After lunch I decided to visit friend owl in his stronghold, which was some 20 feet below where we had decided to eat our lunch. Upon seeing me, the owl which was fully feathered, put up a wonderful, and I suppose it hoped, frightening performance. It stood up, leaned forward, and fluffed itself out as much as possible, drooping and spreading its wings. It then snapped open and shut its eyes, first together, then alternately, and loudly clacked its beak. I wanted to giggle, but felt that this would spoil the dignity of its act. I withdrew, seeming to be properly impressed-I was too, in a way-and 
told the boys to go down and call on it, which they did. They were as delighted as I with its behaviour and we were all sorry that we had no movie camera. I believe it was a Short-eared Owl.

There were many wildflowers growing along the creek below-especially the mauve fleabane, Erigeron philadelphicus. There was a colourful showing of a nice blue Speedwell, probably Veronica americana. There was a good growth of trees in this area, mostly Balsam Poplar, White Spruce and Beaked Willow. The Silverberry, Shrubby Cinquefoil and Gooseberry

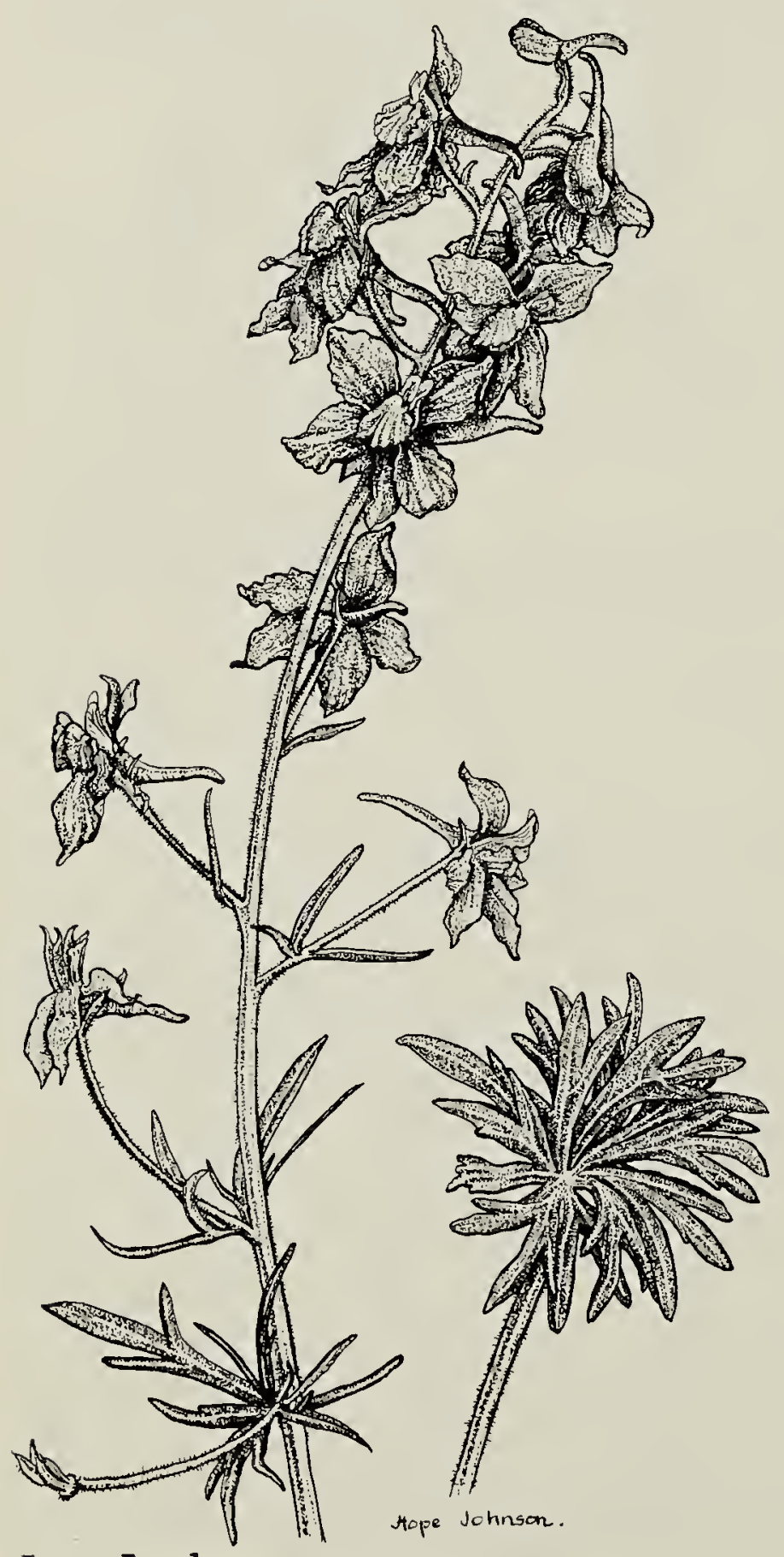

Low Larkspur were common, and some Canada Buffaloberry.

Back along Calf Creek there were tall buttercups growing in the stream margins, and tucked under prooseberry bushes I saw plants of the Mealy Primrose (Primula incana). In moist places there was plenty of Silverweed with its buttercup-like flowers, and strawberry-like runners. There were Buffalo Beans, four Penstemons, Ascending Milk Vetch, Late Yellow Loco Weed, Western Wild Bergamot, Wild Gaillardia, Lewis' Flax, Silvery Groundsel, Cut-leaved Anemone, Crocus Anemone, Wild Strawberry, Pale Comandra, Clustered Oreocarya, Silvery Lupine, Three-flowered Avens and Shining Arnica. A sort of film of the small white flowers of what I took to be Rocky-ground Sandwort covered all the surface of the more open ground. The spring had been very late, so it appeared that the spring and summer flowers were in bloom together.

As for fauna, there were Mule Deer, cattle (which we were obliged to drive off periodically), Richardson's Ground Squirrel and birds. Mostly I noticed Robins and surprisingly, to me, the Oregon Junco, which I had not seen since living out at the West Coast, some twenty-five years ago. The "gophers" were a pest, since they evidently regarded the commissary arrangements of the expedition especially laid on for their benefit. It was difficult to find enough metal containers to keep them even partly frustrated. There must have been general mourning among them when the R.O.M. party took off to Milk River!

The collecting work was interrupted rather too frequently during my four-day stay by squally showers with very gusty winds. The camp was under canvas, and there were times when rain would make things a bit miserable. To my surprise, the boss, Dr. Edmund, was chief cook. I earned my keep, at least in part, by peeling potatoes and scrubbing some of the pots, etc. The impact of the Cypress 
Hills countryside on the Toronto stulents was most satisfactory. One lad, in a chilly damp morning, when I uggested that it was not a very good morning, insisted that "Down here, it s always a good morning!" A few lad periodic longings for bright lights not very handy to Eastend). One vening a bunch of us crammed ourelves into a tent and for hours sang rordon Lightfoot songs. One of the oys had a "double-decker bed" of a hew kind-his regular cot above, and collection of bones and stones below "my bone-bed" as he said!

I was interested to find that one of he two Museum technicians had ormerly been an operating room echnicians working with doctors on roken human bones, while the other vas a former resident of Liverpool, England, with a Beatle-like accent, nd years of experience as a plasterer $n$ the building trade. Not long after oming to Toronto, he had been hired o work at the Museum under a isplay-planner, to build an artificial nineral cave. When his boss gave ip on the job, Jerry, finding his new ccupation much more to his liking han work on houses, stayed on, puting his skills in plastering and contruction to work with fossils and ninerals. It was his first season in he field, and he told me he never vanted to go back to his former occuation, as the new one seemed to offer o many new and exciting possibiliies.

After a four-day stay, the weather hreatened to turn very wet, and I ecided to get out while the going ras good. I took the new road down - Eastend, west to Govenlock, north ast the Cypress Hills Park, up to Maple Creek and out to the Translanada Highway. Near the Alberta order I encountered pouring rain, so was rather glad I had got out of the ills. Later in the summer I went ollecting several times in the Oldman ormation (late Upper Cretaceousinosaurs, etc.) along the Red Deer liver with Dr. Dale Russell of the National Museum of Canada, and also

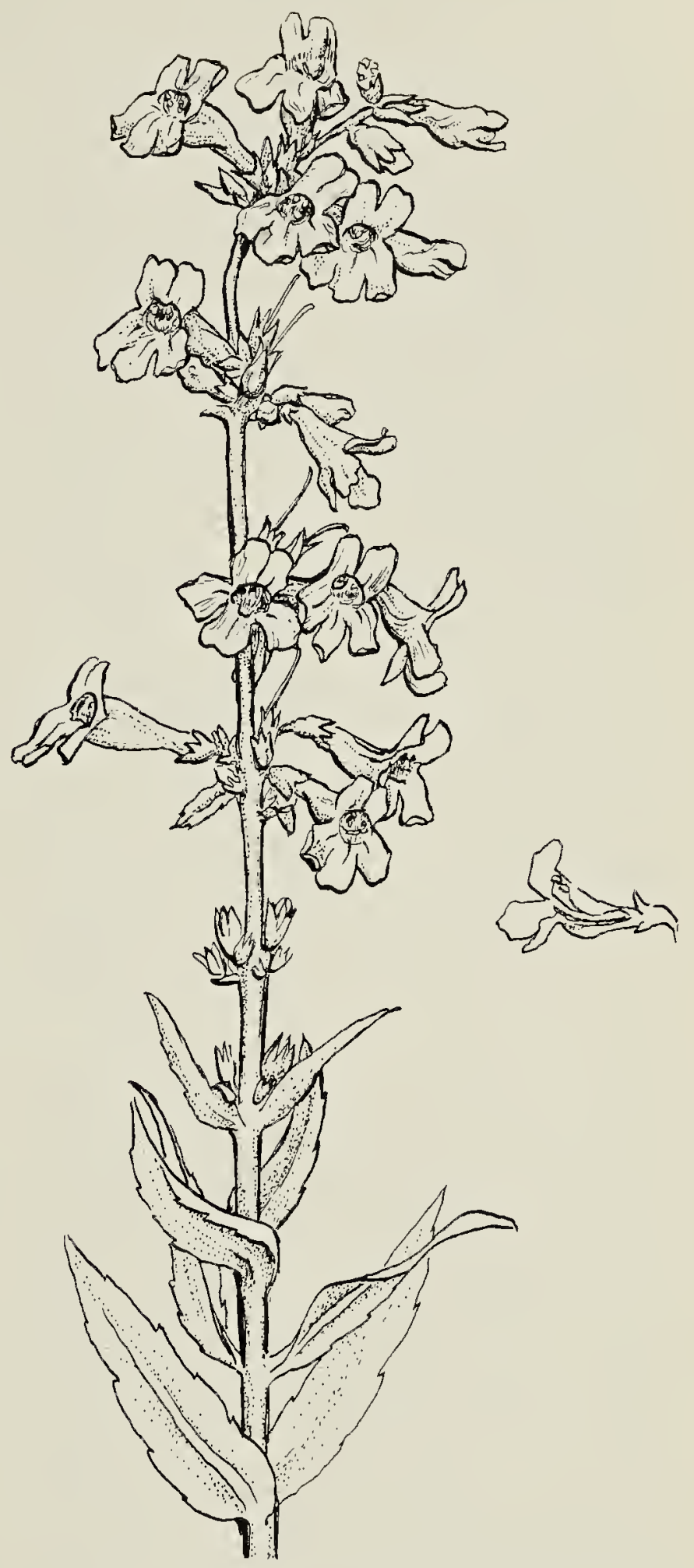

Drawings by Hope Johnson

White Penstemon

along the South Saskatchewan River, collecting fossil wood with Dr. Wilson Stewart, a palaeobotanist, who is now head of the Botany Department at the University of Alberta. However, my trip to the Saskatchewan end of the Cypress Hills has left me with a yen to go back to Calf Creek. 